\title{
The Effects of Fermenters and Incubation Periods on the Chemical Composition of Mixtures of Rice Bran and Water Hyacinth Leaves Meals
}

\author{
Wahyu Karyani, Syamsuhaidi Syamsuhaidi, and K.G. Wiryawan* \\ Faculty of Animal Science The University of Mataram. Jalan Majapahit 62 Mataram INDONESIA. \\ *Corresponding author: K_wiryawan@unram.ac.id
}

\begin{abstract}
Rice bran is a feed material that is commonly given to poultry, but the amount of its use is relatively low because of its high fiber content. Water hyacinth (Eichhornia crassipes) leaf has a chemical composition similar to rice bran and its availability is abundant but its quality as feed material for poultry is also low because of the high content of the fiber. Some studies showed that fermentation could improve the nutrient content of feedstuffs. A study was conducted to evaluate the efficacy of fermentation using two different cultures incubated for $0,7,14$, and 21 days. The results showed that protein contents did not differ significantly between the two microbial cultures, but the mixture of rice bran and water hyacinth leaves fermented using a culture containing 5 types of microbes resulted in lower fiber content. The duration of incubation significantly affected both the fiber and protein content. It was concluded that the nutrient content of the mixture of rice bran and water hyacinth leaves could be improved by fermentation using a microbial mixture for 14 days.
\end{abstract}

Keywords: Fermentation, Rice bran, Water hyacinth leaves, Microbial mixture

\section{INTRODUCTION}

The availability of quality animal feed is one of the determining factors in the success of the livestock industry. Raw feed materials currently used in formulating ration for poultry in Indonesia include fish meal, soybean meal, and meat bone meal, which are relatively expensive compared to other feed ingredients. Therefore, a continuing effort in providing feed based on local resources must be pursued to empower farmers and sustainability of poultry production in Indonesia.

Rice bran is a common feed ingredient available for poultry feed, but its use is limited by high fiber and relatively low protein contents. Farrel and Martin [1] showed that increasing the amount of rice bran in the duckling diet significantly reduced growth performances. On the other hand, water hyacinth (Eichhornia crassipes. Mart.) is one of the aquatic plants that is often regarded as a weed that is economically detrimental to humans. Their abundant and uncontrolled growth in open ponds, irrigation, and other water bodies, are frequently noted in the literature as one of the world's most problematic weeds $[2,3]$. The utilization of this weed as alternative feed not only be an effort to clean water resources from weed, but also provide a farmer with cheap and locally available feed source [4]. However, as with rice bran, the level of its uses in poultry feed is also limited because of its high fiber content.

Fermentation technology has been shown to improve the quality of fibrous feedstuffs [5]. The degree of improvements depends upon several factors such as types of fermenter used and duration of incubation periods. The longer the incubation period the better the results Kasmiran [6], Wibawa et al. [7] Superianto et al. [8], Irawati et al. [9], and Mahmilia [10] reported that fermentation of water hyacinth leave meal using Trichoderma harzianum improved the nutritional value of water hyacinth leaves meal. Crude protein increased by $61.81 \%$ (from $6.31 \%$ to $10.21 \%$ ) and crude fibre decreased $18 \%$ (from $26.61 \%$ to 
$21.82 \%$ ). Studies conducted by Mangisah et al. [11] showed that fermentation of water hyacinth leaves using Aspergillus niger up to three weeks incubation periods indicates that crude protein levels of water hyacinth increased by $13.55 \%$ and the crude fiber content decreased by $19.67 \%$. Fermentation also improves the quality of rice bran [7], and reduces the concentration of the activities of antinutritional factors such as trypsin inhibitors and phytic acid. Fermented rice bran using Aspergillus $s p$ can be included in layer diet up to $50 \%$ [12]. However, the fermentation process is somewhat complex so it is difficult to apply in the farmer environment. Currently, there are different types of probiotics that contain a mixture of microbes available in the market. A fermentation of duckweed using a probiotic containing five species of microbes with the commercial name 'Hen-Bos' [13] showed that crude fiber content decreased from 21 to $10 \%$ and protein content increased from $23 \%$ to $29 \%$. This study examined the effect of fermentation using EM-4 (probiotic with 3 types of microbes) or Hen-Bos on the mixture of water hyacinth leaves meal and rice bran (=WHRB) incubated in different periods on chemical composition.

\section{MATERIALS AND METHODS}

The experiment consisted of two stages i.e., preparing fermenters and preparing materials. Two fermenters or "probiotics" were evaluated. Fermenter 1 is a fermenter containing 5 microbes e.g., Lactobacillus sp, Bacillus sp, Pseudomonas sp, Azotobacter $s p$, and Saccharomyces $s p$, with a commercial name 'Hen-Bos'and Fermenter 2 (EM-4) is a fermenter containing three types of microbes such as Lactobacillus casei; Saccharomyces cerevisiae, and Rhodopseudomonas palustis. Both fermenters were reproduced by diluting $200 \mathrm{ml}$ fermenter into 251 water and fortified with sugar, mineral supplement, and shaked egg to supply nutrients needed for the microbes. Both fermenters were kept in a sealed container at room temperature for 3 days.

Water hyacinth leaves were collected from 'Dam Batu Jai' in Central Lombok, chopped manually so that the size was $\leq 1 \mathrm{~cm}$, exposed under the sun up to constant weight then, ground using a hammer mill to pass $2 \mathrm{~mm}$ screen. The meal was then mixed thoroughly with rice bran in a ratio of $1: 1(\mathrm{w} / \mathrm{w})$. The following step was spraying the fermenter onto the surface of the mixture and mixing it thoroughly. The amount of fermenter applied to the mixture was adjusted so that the moisture content of the mixture was approximately
$60 \%$. Then, the mixture was loaded into 24 plastic containers, sealed to provide an aerobic environment, and stored at room temperature. The incubation periods lasted for $0,7,14$, and 21 days representing treatment $1,2,3$, and 4 respectively. A completely randomized design with a factorial 2X4 arrangement in which each treatment had three replicates was adopted. At the determined time, the leads of the containers were opened to unload the content. After that, the mixtures were subjected to proximate analyses to determine the chemical composition using the standard method [14]. The data were analyzed using PROC GLM of SAS [15].

\section{RESULTS AND DISCUSSIONS}

\subsection{The effects of the fermenter}

Fermentation is a metabolic process in which a carbohydrate, such as starch or sugar is converted into alcohol and acid by bacteria or fungi in an anaerobic environment. Results of laboratory analyses of WHRB before and after fermentation using two different fermenters and different incubation periods are presented in Table 1. No significant difference was observed in the effects of both fermenters on moisture, crude protein, and Nitrogen Free Extractives (NFE) contents. However, both fermenters showed different effects on the concentration of ash, crude fat, and crude fiber. Both EM-4 and Hen-Bos are can be used to reduce the fiber content of a feedstuff.

Ash and crude fat contents of WHRB fermented with fermenter 1 ('Hen-Bos') were higher than those fermented with fermenter 2 (EM-4), whereas the fiber content was lower. The reason for this discrepancy is not clear. These could be associated with the presence of cellulase produced by Bacillus sp. which alters cell wall structure permitting the release of intracellular lipids. Zuorro et al. [16] showed that the enzymatic treatment produced significant alterations in the algal cell wall structure, with extensive loss of cell boundaries and release of intracellular material including lipids. The higher crude fat content of the mixture after fermentation with Hen-Bos may also be due to changes in lipid, fatty acids, and phospholipids composition by the action of fungi [17]

The lower fiber content for the mixture fermented with Hen-Bos not only because of the conversion of the fiber into lactic acid by Lactobacillus $s p$. but also due to the production and activity of cellulase produced by Bacillus sp. [18] which is not present in EM-4, and by the activity of enzyme released by other microbes. 
Table 1. The effects of fermenters and incubation periods on the chemical composition of the mixture of rice bran and water hyacinth leaves meal.

\begin{tabular}{|c|c|c|c|c|c|c|}
\hline Treatments & $\begin{array}{l}\text { Moisture } \\
\text { (\%) }\end{array}$ & Ash (\%) & $\begin{array}{l}\text { Crude Fat } \\
\text { (\%) }\end{array}$ & $\begin{array}{l}\text { Crude } \\
\text { Fiber } \\
(\%)\end{array}$ & $\begin{array}{l}\text { Crude } \\
\text { Protein (\%) }\end{array}$ & NFE (\%) \\
\hline \multicolumn{7}{|l|}{ Fermenter } \\
\hline Fermenter 1 (Hen-Bos) & 9.42 & 15.57 & 4.58 & 17.33 & 12.65 & 39.53 \\
\hline Fermenter 2 (EM-4) & 9.52 & 14.90 & 4.12 & 17.83 & 12.59 & 42.05 \\
\hline SEM & 0.087 & 0.106 & 0.073 & 0.143 & 0.125 & 0.303 \\
\hline Statistics & NS & ** & ** & * & NS & NS \\
\hline \multicolumn{7}{|l|}{ Incubation periods } \\
\hline Day 1 & $9.25^{b}$ & $12.39 c$ & $2.92^{d}$ & $18.06^{a}$ & $12.19^{b}$ & $45.17^{a}$ \\
\hline Day 7 & $9.26^{b}$ & $16.99^{a}$ & $4.86^{b}$ & $17.94^{\mathrm{a}}$ & $12.25^{b}$ & $38.69^{c}$ \\
\hline Day 14 & $9.44^{b}$ & $15.81^{b}$ & $4.44^{c}$ & $17.16^{b}$ & $12.97^{\mathrm{a}}$ & $40.16^{b}$ \\
\hline Day 21 & $9.94^{a}$ & $15.74^{b}$ & $5.20^{a}$ & $17.13^{b}$ & $13.07^{a}$ & $38.92^{c b}$ \\
\hline SEM & 0.123 & 0.150 & 0.103 & 0.203 & 0.177 & 0.429 \\
\hline Statistics & $* \star$ & $* \star$ & $* \star$ & $\star \star$ & $\star \star *$ & ** \\
\hline $\begin{array}{l}\text { Interaction } \\
\text { Fermenter*Period }\end{array}$ & * & NS & $\star \star *$ & * & NS & NS \\
\hline
\end{tabular}

*Significant at $\mathrm{P}<0.05$; **Significant at $\mathrm{P}<0.01$ ); $\mathrm{NS}=$ not significant; $\mathrm{SEM}=$ standard error of the means; NFE $=$ Nitrogen Free Extractives

\subsection{The effects of incubation periods}

Table 1 showed that the incubation periods significantly affected the chemical composition of the mixture of water hyacinth leaves meal and rice bran. The moisture content did not significantly increase up to $14 \mathrm{~d}$ incubation, but those incubated for $21 \mathrm{~d}$ were significantly $(\mathrm{p}<0.01)$ higher than others. This indicates that the extension of the incubation period endorsed the yeast to degrade the NFE components into carbon dioxide and water. Besides, the growth and development of those fungi themselves could have contributed to the increase of moisture content. The result of this study is in line with those reported by [19] who showed a linear relationship between the duration of the incubation period and the moisture content of the substrate.

Extension of incubation period up to 21 days brought about significant increases in ash, crude fat, and crude protein contents which could be due to the activity of microbes and the addition of protein from microbial cells themselves. Another assumption that might explain causes an increase in crude protein content is the ability of yeast in the fermenter to convert nitrogen into protein. These polypeptide microbes can produce protease enzymes that can break down proteins into polypeptides, then into simple peptides, and then these peptides are broken down into amino acids. Then, these amino acids are used by microbes to reproduce themselves. The increase in the number of microbes during the fermentation process indirectly increases crude protein content because microbes are a single cell protein source. Our results were in agreement with the finding of Irawati et al. [9] who noted that the protein content of samples incubated for 21 days was significantly higher than that incubated for 7 days.

Both the length of the incubation period and the two types of fermenter did not have much effect on 
protein content, but the fiber content fermented for 21 days was slightly lower than that fermented for 7 or 14 days. In terms of fiber content, it may take a longer time for more fiber degradation to occur.

There is a significant interaction between the type of fermenter, the ratio of rice bran and water hyacinth leaf, and the length of the incubation period, meaning that fermentation using EM- or Hen-Bos with different ratios or other incubation periods gives different results.

\section{CONCLUSION}

The nutritional content of a mixture of water hyacinth leaves and rice bran can be increased through the application of fermentation technology using cocktail culture containing can be used EM-4 because it is cheap and easy to obtain, and the ratio chosen is 1: $1(\mathrm{w} / \mathrm{w})$ based on dry matter.

\section{AUTHORS' CONTRIBUTIONS}

The Research proposal was initiated and drafted by the first, then discussed by all. The second and first authors did the laboratory works. Statistical analyses and drafting the manuscript were the job of the third/corresponding author. The manuscript was intensively discussed before submission.

\section{ACKNOWLEDGMENT}

The author would like to thank the University of Mataram, through LPPM, for providing financial support for the implementation of this research activity.

\section{REFERENCES}

[1] D. J. Farrell and E. A. Martin, "Strategies to improve the nutritive value of rice bran in poultry diets. I. The addition of food enzymes to target the non-starch polysaccharide fractions in diets of chickens and ducks gave no response," British Poultry Science, 1998, 39:555-559. Doi: 10.1080/00071669888755.

[2] Vinu M. Nampoothiri, “Aquatic plants and marine waste as animal feed," Scholars Journal of Agriculture and Veterinary Sciences, 4(6):249-54. Retrieved June 2120121 (http://saspjournals.com/sjavs-31).
[3] W. Su, Q. Sun, M. Xia, Z. Wen, and Z. Yao, "The resource utilization of water hyacinth (Eichhornia crassipes [Mart.] Solms) and its challenges," Resources, 2018, 7(3) 46,46; Doi: 10.3390/resources7030046.

[4] E. Hossain, H. Sikder, H. Kabir, and S. Sarma, "Nutritive value of water hyacinth (Eichhornia crassipes)," Online Journal of Animal and Feed Research, 2015, 8(1); 26-33 Doi: 10.14941/grass.30.151.

[5] T. Pasaribu, "Produk fermentasi limbah pertanian sebagai bahan pakan unggas di Indonesia," Wartazoa, 2007, 17(3): 109-116.

[6] A. Kasmiran, "Pengaruh Lama Fermentasi Jerami Padi dengan Mikroorganisme Lokal terhadap Kandungan Bahan Kering, Bahan Organik, dan Abu," LENTERA, 2011.

[7] A. A. P. Wibawa, W. Wirawani, and I. B. G. Partama, "Peningkatan Nilai Nutrisi Dedak Padi Sebagai Pakan Itik Melalui Biofermentasi dengan Khamir," Majalah Ilmiah Peternakan, 2015 ,

Doi: 10.24843/MIP.2015.v18.101.p03

[8] S. Superianto, A. E. Harahap, and A. Ali, "Nilai Nutrisi Silase Limbah Sayur Kol dengan Penambahan Dedak Padi dan Lama Fermentasi yang Berbeda," Jurnal Sain Peternakan Indonesia, 2018 13(2): 172-181, Doi: 10.31186/jspi.id.13.2.172-181.

[9] E. Irawati, E. Purnamasari, and F. Arsyad, "Kualitas fisik dan nutrisi eceng gondok (Eichornia crassipes) dengan lama fermentasi yang berbeda," Jurnal Peternakan, 2019, 16(1): 18-24. Doi: 10.24014/jupet.v16i1.3679.

[10] F. Mahmilia, "The change of the nutritional value of the fermented Eichhornia crassipes Mart meal as broiler rations," Jurnal Ilmu Ternak Dan Veteriner, 2005, 10(2): Doi. 10.14334/jitv.v10i2.460

[11] I. Mangisah, T. Tristiarti, W. Murningsih, M. H. Nasoetion, E. S. Jayanti, and Y. Astuti, "Digestibility of Aspergillus Niger-Fermented Eichchornia Crassipes in Broiler," Journal of 
Indonesian Tropical Animal Agriculture, 2006. 31 (2):124-128.

[12] S.Wahyuni, D. C. Budinuryanto, H. Supratman dan Suliantari. 2011. Respon broiler terhadap pemberiaan ransum mengandung dedak padi fermentasi oleh kapang Aspergillus ficuum. Jurnal Ilmu Ternak. 2011, 10 (1) : 26-31.

[13] Y. A. Ayuni, Syamsuhaidi, and K. G. Wiryawan, "The effects of graded levels of fermented duckweed in quail diets on egg production and yolk cholesterol," in IOP Conference Series: Earth and Environmental Science, 2019, vol. 387, no. 1. Doi: 10.1088/1755-1315/387/1/012112.

[14] Association of Official Analytica Chemists, "Official Methods of Analysis of The Association Analytical Chemist," Virginia: AOAC, Inc, 1999.

[15] G. Der and B. Everitt, Handbook of Statistical Analyses Using SAS, Second Edition. 2001. Doi: 10.1201/9781420057553.

[16] A. Zuorro, G. Maffei, and R. Lavecchia, "Optimization of enzyme-assisted lipid extraction from Nannochloropsis microalgae," Journal of the Taiwan Institute of Chemical Engineers, 2016, volume 67 Doi: 10.1016/j.jtice.2016.08.016.

[17] M. Dos, S. Oliveira, V. Feddern, L. Kupski, E. P. Cipolatti, E. Badiale-Furlong, and L. A. de Souza-Soares, "Changes in lipid, fatty acids and phospholipids composition of whole rice bran after solid-state fungal fermentation," Bioresource Technology, 2011, Doi: 10.1016/j.biortech.2011.06.025.

[18] M. Sriariyanun, P. Tantayotai, P. Yasurin, P. Pornwongthong, and K. Cheenkachorn, "Production, purification, and characterization of an ionic liquid tolerant cellulase from Bacillus sp. Isolated from rice paddy field soil," Electronic Journal of Biotechnology, 2016, (16): 23-28. Doi: 10.1016/j.ejbt.2015.11.002.

[19] U. Santoso and I. Aryani, "Perubahan Komposisi Kimia Daun Ubi Kayu yang Difermentasi oleh Em4," Jurnal Sain Peternakan Indonesia, 2007, 2(2):53-56. Doi: 10.31186/jspi.id.2.2.53-56. 